Staurt-Rogers, C. and A. J. Flavell (2001): The evolution of Ty1-copia group retrotransposons in gymnosperms. Mol. Biol. Evol. 18: 155-163.

SteBbins, G. L. (1948): The chromosomes and relationship of Metasequoia and Sequoia. Science 108: 95-98.

StebBins, G. L. (1950): Variation and Evolution in Plants. Columbia University Press, New York.

Stebbins, G. L. (1971): Chromosome Evolution in Higher Plants. Edward Arnold, London.

Syrach-Larsen, C. and M. WestergaARD (1938): A triploid hybrid between Larix deciduas Mill. and Larix occidentalis Nutt. J. Genet. 36: 523-530.

TAKaso, T. and P. B. Tomlinson (1992): Seed cone and ovule ontogeny in Metasequoia, Sequoia and Sequoiadendron (Taxodiaceae, Coniferales). Bot. J. Linn. Soc. 100: 15-37.

The Arabidopsis Genome Initiative. (2000): Analysis of the genome sequence of the flowering plant Arabidopsis thaliana. Nature 408: 796-815.

Thomas, G. and K. K. CHING (1968): A comparative karyotype analysis of Pseudotsuga menziesii (Mirb.) Franco, and Pseudotsuga wisconiana (Hayata). Silvae Genet. 17: 138-143.
TodA, Y. (1996): Karyomorphological studies of the Taxodiaceae. Forest Genetics 3: 141-146.

VAn de Peer, Y., J. S. TAYlor and A. Meyer (2003): Are all fishes ancient polyploids? J. Structural and Functional Genomics 2: 65-73.

Veblen, T. T. and D. H. Ashton (1982): The regeneration status of Fitzroya cupressoides in the Cordillera Pelada, Chile. Biol. Cons. 23: 141-161.

WENDEL, J. F. (2000): Genome evolution in polyploids. Plant Mol. Biol. 42: 225-249.

WolFE, K. H. (2001): Yesterday's polyploids and the mystery of diploidization. Nature Rev. Genet. 2: 323-341.

WRIGHT, J.W. (1976): Introduction to Forest Genetics. Academic Press, New York.

Zhang, S., L. Qi, C. Chen, X. LI, W. Song, B. Chen and S. Hann (2004): A report of triploid Populus of the section Aigeiros. Silvae Genet. 53: 69-75.

ZINNAI, L. (1952): Tetraploid plants in Japanese red pine (Pinus densiflora Sieb. Et Zucc.) discovered in transplant beds. J. Jap. For. Soc. 34: 185-187.

ZINNAI, L. (1953): The morphological characters and the fertility of the pollen of a tetraploid Japanese red pine induced by the colchicines method. J. Jap. For. Soc. 35: 245-248.

\title{
Reproductive Success of Pollen Derived From Selected and Non-Selected Sources and its Impact on the Performance of Crops in a Nematode-Resistant Japanese Black Pine Seed Orchard
}

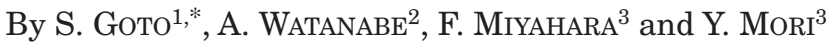 \\ (Received $5^{\text {th }}$ April 2005)
}

\begin{abstract}
The reproductive success of pollen derived from selected and non-selected sources and its impact on the performance of orchard crops were evaluated, using five pairs of microsatellite markers, in a Japanese black pine (Pinus thunbergii Parl.) clonal seed orchard consisting of 16 nematode-resistant clones. The paternity of each open-pollinated seed was determined by comparing the genotypes of seeds from six clones (24 trees) with geno-

1) University Forest in Hokkaido, Graduate School of Agricultural and Life Sciences, The University of Tokyo, Yamabe, Furano, Hokkaido 079-1561, Japan.

2) Forest Tree Breeding Center, Independent Administrative Institution, Ishi, Juo, Hitachi, Ibaraki 319-1301, Japan.

3) Fukuoka Prefecture Forest Research and Extension Center, Toyoda 1438-2, Yamamoto-machi, Kurume, Fukuoka 839-0827, Japan.

*) Communicating author: Susumu Goто, University Forest in Hokkaido, Graduate School of Agricultural and Life Sciences, The University of Tokyo, Yamabe, Furano, Hokkaido 079-1561, Japan. Phone +81-167-42-2111, Fax +81-167-42-2689, E-mail: gotos@uf.a.u-tokyo.ac.jp
\end{abstract}

types of the 16 orchard clones and two trees $(\mathrm{N} 1, \mathrm{~N} 2)$ representing other genotypes that had been inadvertently included in the orchard. Out of 384 seeds examined, the paternity of 316 seeds $(82.3 \%)$ was assigned to the clones within the seed orchard. On average, the male reproductive success of orchard clones varied from $0.0 \%$ to $10.5 \%$, and was significantly related to the male-flowering fecundity of each clone. It was not related to the synchrony of flowering phenology between mates. The expected proportions of seeds produced by clonal trees as a result of pollination by orchard clones, and by contaminating pollen originating from internal and external sources were estimated at $86.8 \%, 3.3 \%$ and $9.9 \%$, respectively. Nematode-resistant seedlings of Japanese black pine were produced from surviving 2-yr seedlings that had previously been inoculated with pinewood nematode (Bursaphelenchus xylophilus). Without pollen contamination, the survival rate of seedlings produced by mating between resistant clones is expected to be $62.4 \%$. However, in this orchard the figure was reduced to $57.5 \%$, due to pollen contamination from both internal and external sources. 
Key words: nematode-resistant, microsatellite, Pinus thunbergii, microsatellite, pollen contamination, reproductive success, seed orchard.

\section{Introduction}

Seed orchards are usually established by the selection, collection, and propagation of phenotypically or genotypically superior trees. Genetic gain calculations are based on complete panmixia in the orchard, taking no account of the possibility of pollination by non-selected trees. However, studies with genetic markers have demonstrated pollen contamination levels of over $30 \%$ in most seed orchards (WHEELER and JECH, 1992 for review; ADAMs et al., 1997; STOEHR et al., 1998; PAKKANEN et al., 2000; MoRIGUCHI et al., 2004). Theoretically, if the superior trees in a seed orchard are all successfully pollinated by trees with non-selected characteristics, the genetic gain would decrease by up to $50 \%$. Therefore, pollen contamination in open-pollinated seed orchards is potentially one of the most serious factors reducing the genetic efficiency of improved seeds. However, few studies have thoroughly examined the impact of pollen contamination on the performance of orchard crops through progeny testing (PlOMion et al., 2001; Goto et al., 2002 b; GrattaPAGLia et al., 2004; STOEHR et al., 2004).

For the successful management of seed orchards, and to prevent contamination, it is essential to identify the source of the pollen. Few reports, however, refer to the source of pollen contamination. ADAMs et al. (1997) suggested that $79 \%$ of the contamination within a block in a Douglas-fir seed orchard came from natural stands, while $21 \%$ was from other blocks in the orchard. In a Sugi (Cryptomeria japonica) seed orchard, about $10 \%$ of the contamination was derived from other blocks in the orchard (MORIGUCHI et al., unpublished). Unfortunately, mis-planting and/or mis-labeling commonly occur within seed orchards (HARJU and MUONA, 1989; WHEELER and JECH, 1992; KaWAUCHI and Gото, 1999; Gото et al., 2001). Occasionally, non-selected genotypes are included amongst the orchard trees as a result of mistakes during the collection or propagation of selected genotypes and as a result of rootstocks overtaking their grafts (VAN DE VEN and MCNiCOL, 1995; KAWAUCHI and GoTO, 1999). Such non-selected trees within the orchard will be internal sources of both pollen and seed contamination. However, the level and influence of non-selected trees within the orchard are not yet fully understood.

The maximum gene diversity for a given number of clones occurs when mating among the seed orchard parents approaches panmixis, and all orchard genotypes contribute equally to the crop (KANG et al., 2001). The contribution of clones as pollen donors has been evaluated, using allozyme or DNA molecular markers, for Picea glauca (Schoen and StewART, 1986), Pseudotsuga menziesii (Stoenr et al., 1998), Pinus thunbergii (Gото et al., 2002a), Pinus contorta (Stoehr and NewTon, 2002), Quercus robur (BUITEVELD et al., 2001), and Cryptomeria japonica (MORIGUCHI et al., 2004). In general, the mating dynamics within orchard clones deviate significantly from panmixis. Not only inter-mate distances, but also several biological factors such as flowering fecundity and synchrony of flowering phenology between mates, affect the male reproductive success of orchard clones (EL-Kassaby et al., 1984; SCHOEN and SteWART, 1986; ERICKSON and ADAMS, 1989; BURCZYK and PRAT, 1997; BURCZYK et al., 2002). To improve the parental balance in a seed orchard, it is necessary to determine the strength of these influences on male reproductive success.

Japanese black pine (Pinus thunbergii Parl.) is a very common and important tree species that is often used in wind breaks to provide protection against sand and salt in coastal areas of Japan. However, during the last five decades the species has been severely affected by pine wilt disease, caused by the pinewood nematode (Bursaphelenchus xylophilus), especially in southwestern Japan. Because of the severity of damage caused by the pest and the importance of Japanese black pine, a research project was initiated in 1978 to examine the selection and production of pinewood nematode-resistant plant material. Within this project, sixteen resistant plus trees of Japanese black pine were selected from 14,620 candidates (Fujiмото et al., 1989). Clonal seed orchards, consisting of these resistant clones, were established through grafting. These seed orchards have played an important role in the reforestation of the coastal area affected by pine wilt disease (TODA et al., 1993). In the Kyushu district, Japan, Japanese black pine plants resistant to pine wilt disease have been produced by inoculating seedlings from the seed orchard with the pinewood nematode (TODA et al., 1993).

In the previous study, we used random amplified polymorphic DNA (RAPD) markers (WILLIAMs et al., 1990) for clonal checking of ramets in the Japanese black pine clonal seed orchard located in Fukuoka prefecture, Japan. As a result, we detected two non-selected trees (N1, N2) within the seed orchard (Goто et al., 2001). These trees will act as internal sources of pollen contamination of the seed orchard (internal pollen contamination, hereafter). In this seed orchard, male reproductive success of orchard clones and pollen contamination were assessed using 45 RAPD markers (GoTo et al., 2002a). The results indicated that the male reproductive success of each orchard clone deviated significantly from the panmictic situation and that pollen contamination was around $2 \%$. This value should be regarded as a minimum estimate of pollen contamination, because some contaminants are likely to have banding patterns indistinguishable from orchard genotypes due to the low polymorphism levels of RAPD markers. Moreover, the source of pollen contamination could not be determined. Recently, microsatellite markers that are co-dominant and characteristically exhibit high levels of polymorphism have been successfully applied to seed orchard studies (BUITEVELD et al., 2001; CHARIX et al., 2003; GRATTAPAGLIA et al., 2004; MORIGUCHI et al., 2004).

In this study, we used microsatellite markers to evaluate the reproductive success of pollen derived from selected and non-selected sources, including both internal and external pollen contamination. We discuss the influence of pollen contamination on the performance of orchard crops, especially on the resistance of seedlings to the pinewood nematode and on the cost of nematoderesistant Japanese black pine seedling production. 


\section{Materials and Methods}

\section{Seed orchard}

The orchard used in this study was the clonal Japanese black pine seed orchard located near Ogoori, in Fukuoka prefecture, Japan. The orchard ( 0.5 ha in size) contains 16 nematode-resistant clones selected during the project on nematode-resistance of Japanese black pines (FuJimote et al., 1989). Ramets were multiplied by grafting, then planted $5 \times 5 \mathrm{~m}$ apart and distributed throughout the orchard according to GIERTYCH (1965). The seed orchard was established in 1988. When established, the seed orchard contained 200 trees and in 2002, at the time of seed collection for this study, 159 mature trees were present within it. The male-flowering fecundity of each tree was recorded during May 1999, the flowering season. We assigned a male-flowering fecundity score (from 1 to 5 ) by visually inspecting the pollen shedding, where 1 and 5 indicated the lowest and highest pollen production, respectively. Flowering phenology was also observed during the flowering season, from $11^{\text {th }}$ April to $7^{\text {th }}$ May 2001, at intervals of two or three days. Thus, the synchrony of phenology between pairs of clones was investigated.

\section{Plant material and DNA analysis}

In October 2002, we collected 384 open-pollinated seeds from 24 maternal trees (Fig. 1), including six clones ( 16 seeds $\times 4$ ramets $\times 6$ clones). Needles of 16 orchard clones and non-selected trees (N1, N2) were also collected for the paternity analysis. For each sample, DNA was extracted using a DNeasy Plant Mini Kit (Qiagen Co LTD) or a Plant Genomic DNA Mini kit (ViogeneBiotek Corp.), from the hypocotyls of each germinated seed or from approximately $150 \mathrm{mg}$ of needles from the adult trees. Microsatellite loci were amplified using five primer pairs. Two primer pairs (pde5 and pde14) were adapted from LIAN et al. (2000), and additional three primers were developed (bcpd006, bcpd015 and

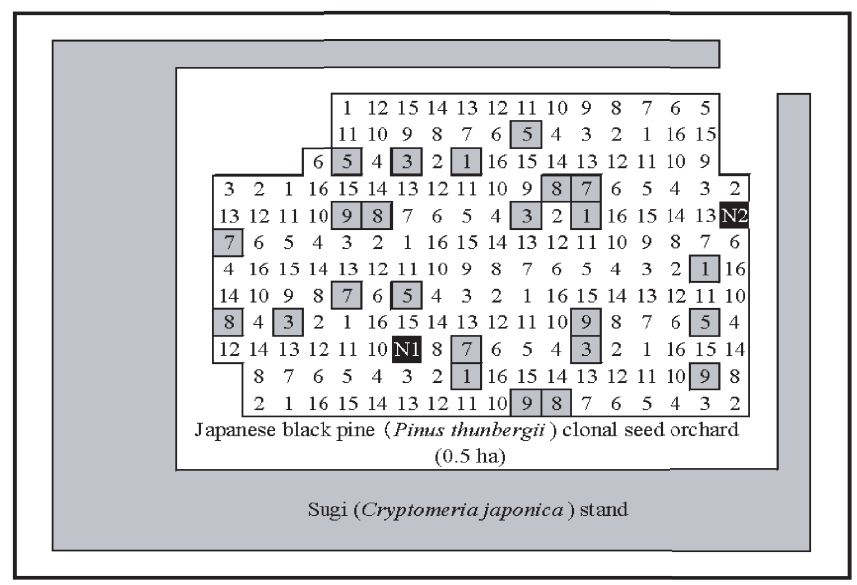

Figure 1. - Layout of the orchard clones and location of maternal and non-selected trees (N1, N2). Nos. 1-16 indicate the designated number of the orchard clones; 1: Namikata(t)-73, 2: Obama(t)-30, 3: Tosashimizu(t)-63, 4: Ooita(t)-8, 5: Ei(t)-425, 6: Tsuyazaki(t)-50, 7: Misaki(t)-90, 8: Ooseto(t)-12, 9: Namikata(t)-37， 10: Tanabe(t)-54，11: Yasu(t)-37，12: Shima(t)-64, 13: Yoshida $(\mathrm{t})-2, \quad$ 14: $\quad$ Sendai $(\mathrm{t})-290$, 15: Mitoyo $(\mathrm{t})-103$ 16: Bizen(t)-143. The squares represent maternal trees used for seed collection in this study. bcpd309) by Watanabe et al. (unpublished). The clonesequences of bcpd006, bcpd015 and bcpd309 contained repeat $(\mathrm{AT})^{5}(\mathrm{GT})^{21},(\mathrm{TA})^{4}(\mathrm{TG})^{20}$, and $(\mathrm{AT})^{4}(\mathrm{GT})^{19}$, respectively. The primer sequences were as follows: bcpd006, forward 5'TATAGTATTGTATGTCTTGAATG, bcpd006; reverse 5'CATCATTGTTATTGCTATCC; bcpd015, forward 5'CAATAACAAATGGTTCCATG; bcpd015, reverse 5'CTAAGGTATTTTTTTCCTCCG; bcpd309, forward 5' GATGTGTCATCTATCCATCCC; bcpd309, reverse 5' ATCTGTGTGGCTCATATTCG. Genotypes were scored according to PCR product length at each locus using a Prism 3100 Genetic Analyzer (ABI) and GeneScan analysis software (ABI).

\section{Paternity assignment}

Genotypes of 384 seeds and 18 candidate paternal parents were determined at five microsatellite loci and paternity of each seed was assigned based on simple exclusion method (Dow and AsHLEY, 1996). Possible paternal alleles at every locus, inferred by subtracting the maternal alleles from the offspring alleles, were compared with the 18 candidates. Genotypes that did not share possible paternal alleles at the locus were considered not to be progeny of the candidate paternal parent. If all 18 genotypes were excluded (no match), we considered that their paternal parent was outside the orchard, thus indicating external pollen contamination. When all but one candidate genotype was excluded (an exact match), we designated that genotype as the paternal parent. Null alleles can cause serious problems when using microsatellite markers, because they can lead to exclusion of the "true" paternal parent (MoRiguchi et al., 2004). Therefore, if a mismatch was detected in the genotypes of maternal clones and their seeds, we assumed the existence of a null allele for the paternity analysis. In such cases, when both the maternal and offspring genotypes were homozygous, they were treated as heterozygotes possessing one null allele. In such cases, the true parent must not be excluded from the possible parents (Dow and AsHLEY, 1996).

\section{Estimating pollen dispersal from a non-selected tree}

The observed genetic contribution $\left(\mathrm{P}_{\mathrm{O}}\right)$ of a non-selected tree was defined as the proportion of the seeds sired by a non-orchard tree as determined by the paternity analysis. The density of pollen dispersed from individual trees decreases rapidly with distance from the source (WANG et al., 1960; Silen, 1962). We assumed that the expected genetic contribution $\left(\mathrm{P}_{\mathrm{E}}\right)$ of a non-selected tree is according to normal distribution, with variance $\tau^{2}$, and can be described by the equation:

$$
P_{E}=\alpha \operatorname{EXP}\left(-\left(d^{2} / 2 \tau^{2}\right)\right)
$$

where $\alpha$ is a constant and $d$ is the distance from the non-selected tree to mother tree. We calculated the sum of squares error of the difference between the observed $\left(\mathrm{P}_{\mathrm{O}}\right)$ and expected genetic contributions $\left(\mathrm{P}_{\mathrm{E}}\right)$. We then used the Solver function in Microsoft Excel to optimize the parameters $\alpha$ and $\tau$ to minimize this error. We applied the model with the best fit to the 159 mature trees in the seed orchard, and thus estimated the internal pollen contamination for the total crop. 


\section{Impact of pollen contamination on the orchard crop}

Nematode-resistant Japanese black pine is produced by inoculating seedlings from the orchard with the pinewood nematode and selecting those that show the resistance. The survival rate of inoculated seedlings is about $62.4 \%$ when the only parents are orchard clones and there has been no pollen contamination (GоTо et al., $2002 \mathrm{~b}$ ). Seedlings sired as a result of pollen contamination have a decreased survival rate: only $25.0 \%$ (Gото et al., $2002 \mathrm{~b}$ ). Based on the survival rates determined by Gото et al. (2002b), we calculated the actual survival rate (As) in this seed orchard as follows:

$$
A s=M O \times 0.624+\{\operatorname{IntPC}+\operatorname{ExtPC}\} \times 0.250
$$

where MO is the proportion of seeds produced by mating between orchard clones, and IntPC and ExtPC represent the proportions of internal and external pollen contamination, respectively. Recently, about 50,000 seedlings in Fukuoka prefecture, Japan, have been inoc-

Table 1. - Allelic diversity of microsatellite loci used in this study.

\begin{tabular}{lccc}
\hline Locus & $\mathrm{k}$ & $\mathrm{H}_{(\mathrm{O})}$ & $\mathrm{H}_{(\mathrm{E})}$ \\
\hline bcpd006 & 9 & 0,833 & 0,765 \\
bcpd015 & 11 & 0,944 & 0,900 \\
bcpd309 & 12 & 0,500 & 0,844 \\
pde5 & 5 & 0,333 & 0,659 \\
pde14 & 11 & 0,722 & 0,862 \\
\hline Mean & 9,6 & 0,666 & 0,806 \\
\hline
\end{tabular}

Allelic diversity is caluculated using 18 parental clones in Pinus thunbergii. $\mathrm{k}$ : the number of alleles, $\mathrm{H}_{\mathrm{E}}$ : expected heterozygosity, $\mathrm{H}_{(\mathrm{O})}$ : observed heterozygosity. Total exclusionary power for the second parent is caluculated as 0.993 using computer program CERVUS 2.0 (MARSHALL et al., 1998). ulated with the pinewood nematode. Of these, 31,200 $(50,000 \times 0.624)$ seedlings would be expected to survive in the absence of pollen contamination. The economic loss was calculated by comparing the real and ideal situations (i.e. with and without pollen contamination), assuming the cost of each nematode-resistant plant to be 500 Japanese yen.

\section{Results}

\section{Allelic diversity of microsatellite loci}

The number of alleles for the 18 candidate genotypes ranged from 5 to 12 , with an average of 9.6 (Table 1 ). The average expected heterozygosity over the five loci was 0.806 . The total exclusion probability for the second parent was 0.993 (MARSHALL et al., 1998). The high polymorphism of the microsatellite loci allows precise determination of paternity. When comparing the genotype of each seed with its maternal clone, a mismatch was detected in seeds at the bcpd006 and bcpd309 loci. This may be caused by the presence of a null allele. Therefore, we assumed the presence of a null allele in these loci in the paternity determinations.

\section{Male reproductive success of orchard clones and influencing factors}

Out of 384 seeds examined, the paternity of 316 seeds $(82.3 \%)$ was assigned to the clones within the seed orchard. Overall, internal pollen contamination by $\mathrm{N} 1$ and $\mathrm{N} 2$ amounted to $3.6 \%$ and $0.0 \%$, respectively (Table 2). External pollen contamination affected $9.9 \%$ of the samples overall. The paternity of 16 seeds $(4.2 \%)$ was assigned to multiple clones, therefore these 16 seeds were excluded from the subsequent analysis. The mean male reproductive success of the six parental clones varied widely, from $0 \%$ for $\operatorname{Ei}(\mathrm{t})-495$ and $\operatorname{Bizen}(\mathrm{d})-143$ to $10.5 \%$ for Tsuyazaki(t)-50. The selfing rate of the six parental clones ranged from $0.0 \%$ to $20.3 \%$, with an

Table 2. - Male reproductive success of orchard clones and internal pollen contamination by non-selected trees (N1, N2) and external pollen contamination.

\begin{tabular}{|c|c|c|c|c|c|c|c|c|}
\hline \multirow[b]{2}{*}{ ID } & \multirow[b]{2}{*}{ Orchard clone } & \multirow[b]{2}{*}{ Namikata(t)-73 } & \multicolumn{5}{|c|}{ Parental clones } & \multirow[b]{2}{*}{ mean } \\
\hline & & & Tosashimizu(t)-63 & $\operatorname{Ei}(\mathrm{t})-495$ & Misaki(t)-90 & Ooseto(t)-12 & Namikata(t)-37 & \\
\hline 1 & Namikata(t)-73 & 0,203 & 0,016 & 0,143 & 0,016 & 0,067 & 0 & 0,074 \\
\hline 2 & Obama(t)-30 & 0,109 & 0,066 & 0,032 & 0,048 & 0,067 & 0,017 & 0,056 \\
\hline 3 & Tosashimizu(t)-63 & 0,031 & 0,066 & 0,016 & 0,032 & 0,017 & 0,086 & 0,041 \\
\hline 4 & Ooita $(t)-8$ & 0,016 & 0,082 & 0,111 & 0,113 & 0,100 & 0,138 & 0,093 \\
\hline 5 & $\operatorname{Ei}(t)-495$ & 0 & 0 & o & 0 & 0 & 0 & 0 \\
\hline 6 & Tsuyazaki(t)-50 & 0,109 & 0,066 & 0,175 & 0,145 & 0,083 & 0,052 & 0,105 \\
\hline 7 & Misaki(t)-90 & 0,156 & 0,033 & 0,048 & 0,065 & 0,117 & 0,052 & 0,078 \\
\hline 8 & Ooseto(t)-12 & 0,156 & 0,098 & 0,111 & 0,032 & 0,133 & 0,086 & 0,103 \\
\hline 9 & Namikata(t)-37 & 0,094 & 0,115 & 0,063 & 0,065 & 0,117 & 0,121 & 0,096 \\
\hline 10 & Tanabe(t)-54 & 0 & 0 & 0,016 & 0,065 & 0,067 & 0,034 & 0,030 \\
\hline 11 & Yasu(t)-37 & 0,016 & 0,033 & 0,095 & 0,065 & 0,017 & 0,034 & 0,043 \\
\hline 12 & Shima(t)-64 & 0,016 & 0,115 & 0,032 & 0,048 & 0,033 & 0,034 & 0,046 \\
\hline 13 & Yoshida(t)-2 & 0 & 0,016 & 0 & 0,032 & 0,017 & 0 & 0,011 \\
\hline 14 & Sendai( $(t)-290$ & 0,031 & 0,131 & 0,032 & 0,065 & 0,100 & 0,103 & 0,077 \\
\hline 15 & Mitoyo(t)-103 & 0,016 & 0 & 0 & 0 & 0 & 0 & 0,003 \\
\hline 16 & $\operatorname{Bizen}(\mathrm{t})-143$ & 0 & 0 & 0 & 0 & 0 & 0 & 0 \\
\hline \multicolumn{2}{|c|}{ Internal pollen contamination (N1) } & 0 & 0,016 & 0,016 & 0,081 & 0,050 & 0,069 & $0,036 *$ \\
\hline \multicolumn{2}{|c|}{ Internal pollen contamination (N2) } & 0 & 0 & 0 & 0 & 0 & 0 & $0 *$ \\
\hline \multicolumn{2}{|c|}{ External pollen contamination } & 0,047 & 0,148 & 0,111 & 0,129 & 0,017 & 0,172 & $0,099 *$ \\
\hline
\end{tabular}

Bold font: Selfing, * Internal and external pollen contamination overall samples. 
Table 3. - Regression analysis of the relationship between male reproductive success and synchrony of flowering phenology, male flowering fecundity of each orchrad clone. The independent variables in the regression is male reproductive success of orchard clone.

\begin{tabular}{|c|c|c|c|c|c|}
\hline Variables & $R^{2}$ & Adjusted $R^{2}$ & $\begin{array}{l}\text { Standardized } \\
\text { coefficient }\end{array}$ & $t$ & $P$ \\
\hline Constant & 0,426 & 0,413 & - & 0,389 & 0,698 \\
\hline Male flowering fecundity & & & 0,652 & 8,286 & $<0.001$ \\
\hline Synchrony of flowering phenology & & & $-0,016$ & $-0,199$ & 0,843 \\
\hline
\end{tabular}

average of $9.8 \%$. The mean flowering fecundity score ranged from 0.09 for Mitoyo(t)-103 to 2.15 for Tsuyazaki(t)-50, excluding Bizen(t)-143 (data not shown). The clone Bizen(t)-143 was introduced to this orchard in 2000 , later than the other clones, therefore male flowers of this clone were very rare during the year of seed collection (2001). The average overlap of the flowering periods of parental clones and paternal candidates was about four days. There was no distinct difference in synchrony between pairs: except that the non-selected tree N2 flowered after most of the orchard's female flowers were finished. Regression analysis indicated that flowering fecundity of orchard clones was strongly associated with male reproductive success, whereas synchrony of flowering phenology was not correlated with it (Table 3).

\section{Estimates of pollen contamination from internal and external pollen sources}

The observed genetic contribution of N2 in this study was $0.0 \%$. This tree produced very few male flowers and its flowering did not coincide with most of the female flowers of the orchard clones. Therefore, we assumed that the influence of $\mathrm{N} 2$ as a male parent in this seed orchard could be ignored. We, therefore, calculated the expected genetic contribution $\left(\mathrm{P}_{\mathrm{E}}\right)$ based on $\mathrm{N} 1$ as the sole internal source of pollen contamination. Parameters $\alpha$ and $\tau$ were assigned values of $12.5 \%$ and $17.5 \mathrm{~m}$, respectively, to minimize the sum of squares error of the difference between $\mathrm{P}_{\mathrm{O}}$ and $\mathrm{P}_{\mathrm{E}}$ (Fig. 2). When we applied this model to all of the 159 mature trees within the seed orchard, the proportion of seeds sired by N1 was estimated as $3.3 \%$ of the total orchard crop. In contrast, outside pollen contamination reaching each female parent tree was not related to their distance from the edge of the seed orchard. Therefore, we applied the amount of external pollen contamination determined in this study $(9.9 \%)$ to the whole orchard crop.

\section{Impact of pollen contamination on the orchard crop}

In this study, the proportion of seedlings produced by mating between orchard clones was estimated at $86.8 \%$ for the total crop. Internal and external pollen contamination was estimated at $3.3 \%$ and $9.9 \%$, respectively. Therefore, the actual survival rate $\left(\mathrm{A}_{\mathrm{S}}\right)$ was predicted to be $0.575(0.868 \times 0.624+(0.033+0.099) \times 0.250)$. When 50,000 seedlings are inoculated, $31,200(50,000 \times 0.624)$ seedlings will survive without pollen contamination. However, only 28,730 (50,000 x 0.575) seedlings will survive in the real situation. Assuming the price of nematode-resistant seedlings is 500 Japanese yen, the gross cost of the difference is $15,600,000$ minus $14,365,227$

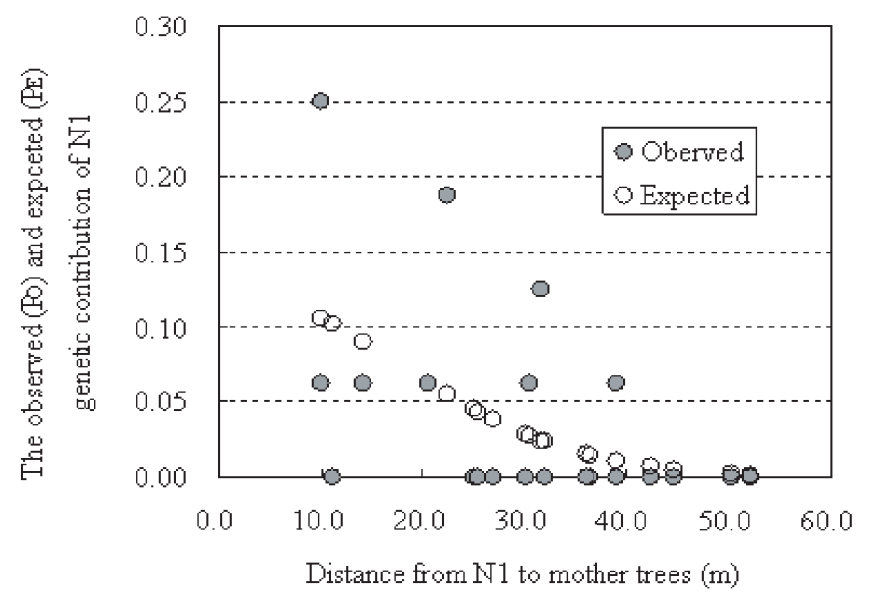

Figure 2. - The observed $\left(\mathrm{P}_{\mathrm{O}}\right)$ and expected $\left(\mathrm{P}_{\mathrm{E}}\right)$ genetic contributions of $\mathrm{N} 1$ to the seeds for each of the maternal trees and the distance from $\mathrm{N} 1$ to each maternal tree. The observed genetic contribution $\left(\mathrm{P}_{\mathrm{O}}\right)$ of the non-selected tree $\mathrm{N} 1$ was defined as the proportion of the seeds sired by N1, determined by paternity analysis. The expected genetic contribution $\left(\mathrm{P}_{\mathrm{E}}\right)$ was based on a normal distribution with variance $\tau^{2}$ : where $a$ is a constant and $d$ indicates the distance from $\mathrm{N} 1$ to each mother tree. The optimized parameters $\alpha$ and $\tau$ were $12.5 \%$ and $17.5 \mathrm{~m}$, respectively.

Japanese yen. Therefore, the economic loss was calculated as 1,234,733 Japanese yen (corresponding to over 9,000 Euro\$).

\section{Discussion}

The exclusion probability over the five loci was high (0.993), indicating that high levels of polymorphism guarantee precise paternity assignment for orchard crops. In this study, out of 384 seeds surveyed, the paternity of 368 seeds $(95.8 \%)$ could be assigned using only five pairs of microsatellite markers. Gото et al. (2002a) identified the male parent of 559 out of 648 seedlings $(86.3 \%)$ using 45 RAPD markers. Therefore the use of microsatellite markers greatly improved the precision and efficiency of the paternity analysis.

Mating between orchard clones deviated significantly from panmixis $\left(\chi^{2}=60.6, \mathrm{p}<0.001\right)$. The male reproductive success of each clone varied from 0.0 to $10.5 \%$ in this seed orchard (Table 2). Studying the same seed orchard, Gото et al. (2002a) found a greater deviation from panmixis $\left(\chi^{2}=218.0, p<0.001\right)$ than reported here. There is greater parental balance in a mast year than in a year of poor seed production (SEIDO, 2001). However, the seeds were collected in 1997 (Gото et al., 2002a) and 2002 (this study), both of which were mast years, so this 
cannot explain the difference in deviation from panmixis. Parental balance may be improved as the seed orchard matures. Flowering phenology often affects male reproductive success (EL-KASSABY et al., 1984; ERICKSON and ADAMS, 1989; BURCZYK and PRAT, 1997; BURCZYK et al., 2002). The orchard clones used in this seed orchard have been selected from a relatively restricted area (southwestern Japan), and the flowering of the clones in the orchard is almost synchronous (TODA et al., 1994). This explains the absence of a relationship between synchrony of flowering phenology and male reproductive success. In contrast, the fecundity of male flowers differs between clones and is closely related to the male reproductive success of each clone (Table 3 ). Such relationships have been recorded in a white spruce seed orchard (Schoen and StewART, 1986) and a Douglas-fir seed orchard (BURCZYK and PRAT, 1997). The same clones contributed most as male parents to the orchard crop in both this study and the previous RAPDbased study by Gото et al. (2002a). The male-flowering characteristics of Japanese black pine appear to be genetically stable (ToDA et al., 1993). Therefore, clones that display lower fecundity and lower male reproductive success should be replaced by newly selected clones in order to improve the parental balance.

The level of self-fertilization detected in this seed orchard (9.8\% on average) is similar to that the levels recorded in other seed orchards (BURCZYK and PRAT, 1997; Stoenr et al., 1998; SEIDO, 2001; STOEHR and NEWTON, 2002; MORIGUCHI et al., 2004). In conifers, self-fertilization adversely affects embryo development, seed germination, and survival of young seedlings, due to inbreeding depression (LIAN et al., 2001). TANG and IDE (1998) investigated the genetic variation in both seeds and 1-, 2- and 3-year-old seedlings of Chamaecyparis obtusa. They found that both observed and expected heterozygosities were higher in older seedlings than in young ones. They suggested that natural thinning of inbred offspring, including those produced through selffertilization, occurred prior to their transplantation in the nursery. Amongst 2-yr seedlings in the nursery, Gото et al. (2002a) detected only $1.5 \%$ that was the result of self-fertilization. Therefore, selfing should not be a serious problem in this seed orchard.

We assessed the influence of non-selected trees within the seed orchard on pollen contamination. The internal pollen contamination, from N1, affected $3.3 \%$ of the total crop. Pollen dispersion from N1 was estimated based on a normal distribution with variance $\tau=17.5 \mathrm{~m}$ (Fig. 2). The curve of pollen dispersion of single tree seems reasonable when compared with data from other wind-pollinated tree species, such Japanese red pine (Pinus densiflora) (LiAN et al., 2001), Quercus petraea and $Q$. robur (STREIFF et al., 1999). If all 159 mature trees within the seed orchard contribute equally to the orchard crop, the genetic contribution of each tree would be $1 / 159(0.6 \%)$. Therefore, the expected genetic contribution $\left(\mathrm{P}_{\mathrm{E}}\right)$ of $\mathrm{N} 1$ is remarkably high. This tree was a heavy producer of pollen (Y. Mori and F. Miyahara, personal observation), which may account for its high genetic contribution. In contrast, N2 did not contribute to reproduction within the seed orchard. N1 was located in the center of the orchard, whereas N2 was at the edge (Fig. 1). Moreover, the flowering fecundity of N2 was very low, and its flowering phenology was not synchronized with most of the orchard clones. Thus, the influence of a non-orchard tree within the seed orchard may depend on its flowering characteristics and its location within the orchard.

The estimate of external pollen contamination in this study was lower than values reported previously in other seed orchards, where it can exceed $30 \%$ (ADAMs et al., 1997; StOEHR et al., 1998; PAKKANEN et al., 2000; ChaIX et al., 2003; Moriguchi et al., 2004). External pollen contamination usually depends on the density of conspecific natural stands around the seed orchard. Since no natural pine forests exist within at least $1 \mathrm{~km}$ of the seed orchard, we suggest that the lack of adjacent natural populations of Japanese black pines may prevent high levels of external pollen contamination.

Pollen contamination effects on progeny performance are likely orchard specific, and therefore, each orchard should be tested for these effects (STOEHR et al., 2004). GRATTAPAGLIA et al. (2004) identified the paternity of offspring produced by one female tree in a progeny testing field of superior growth in Eucalyptus. They showed that the proportion of offspring sired by external pollen donors in the selected population was significantly higher than in a non-selected tree population. On the other hand, STOEHR et al. (2004) made the controlled pollination with outside orchard pollen and inside orchard pollen on trees of a Douglas-fir costal-interior transition zone seed orchard, and they reported that the trees height difference due to pollen source were statistically non-significant. In case of the Japanese black pine seed orchard consisting of nematode-resistant clones, pollen contamination will strongly influence the performance of orchard crops, because the resistance against the nematode was remarkably lower in seedlings derived from non-selected populations than in those from selected populations (FUנIмото et al., 1989; TODA et al., 1993; Gото et al., 2002b). We estimated the internal and external pollen contamination to the total of orchard crops was $3.3 \%$ and $9.9 \%$, respectively. In spite of relatively low level of pollen contamination, the survival rates following inoculation will decrease from $62.4 \%$ to $57.5 \%$ and the financial loss was calculated as $1,234,733$ Japanese yen (corresponding to over 9,000 Euro\$). Thus, the impact of pollen contamination from internal and external sources is serious. Clonal checking of ramets within the seed orchard is essential for determining the source of internal pollen contamination (Gото et al., 2001). Several orchard management techniques, such as supplemental mass pollination (SMP) (STOEHR et al., 1998) and gibberellin $\mathrm{A}_{4 / 7}$ treatment (ToDA et al., 1993), can enhance orchard clones' pollen production. Rigorous clonal checking and application of these techniques should be encouraged to prevent internal and external pollen contamination in Japanese black pine seed orchards.

\section{Acknowledgements}

The authors would like to thank T. HoGETsu for critical reading of a previous draft of this paper. The authors also 
thank Y. MoRIGUCHI for helpful suggestions about this paper, Y. TSUDA for DNA analysis, and H. IwATA for statistical suggestions. The study was supported in part by Grants-in id for Scientific Research (Nos. 16101008 and 15780112) from the Ministry of Education, Culture, Sports, Science and Technology, Japan.

\section{Literature cited}

Adams, W. T., V. D. Hipkins, J. BurczyK and W. K. RANDALL (1997): Pollen contamination trends in a maturing Douglas-fir seed orchard. Can J For Res 27: 131-134.

Butteveld, J., E. G. BAKkeR, J. Bovenschen and S. M. G. DE VRIES (2001): Paternity analysis in a seed orchard of Quercus robur L. and estimation of the amount of background pollination using microsatellite markers. For Genet 8: 331-337.

BurczYK, J., D. PRAT (1997): Male reproductive success in Pseudotsuga menziesii (Mirb.) Franco: the effects of spatial structure and flowering characteristics. Heredity 79: $638-647$.

BurczyK, J., W. T. Adams, G. F. Moran and A. R. Griffin (2002): Complex patterns of mating revealed in a Eucalyptus regnans seed orchard using allozyme markers and the neighbourhood model. Mol Ecol 11: 2379-2391.

Chaix, G., S. Gerber, V. Razafimaharo, P. Vigneron, D. VERHAEGEN and S. HAMON (2003): Gene flow estimation with microsatellites in a Malagasy seed orchard of Eucalyptus grandis. Theor Appl Genet 107: 705-712.

Dow, B. D. and M. V. Ashley (1996): Microsatellite analysis of seed dispersal and parentage of saplings in bur oak, Quercus macrocarpa. Mol Ecol 5: 615-627.

El-Kassaby, Y. A., A. M. K. FASHLER and O. SzIKLAI (1984): The role of reproductive phenology and its impact on genetically improved seed production in a Douglas-fir seed orchard. Silvae Genetica 33: 120-125.

ERICKSON, V. J. and W. T. AdAMs (1989): Mating success in a coastal Douglas-fir seed orchard as affected by distance and floral phenology. Can J For Res 19: 1248-1255.

Fujimoto, Y., T. Toda, K. Nishimura, H. Yamate and S. FUYUNO (1989): Breeding project on resistance to pinewood nematode - An outline of the research and the achievement of project for ten years. Bull For Tree Inst 7: 1-84 (in Japanese with English summary).

GiERTyCH, M. M. (1965): Systematic lay-outs for seed orchards. Silvae Genetica 14: 91-94.

Goto, S., F. MryahaRA and Y. IDE (2001): A fast method for checking the genetic identity of ramets in a clonal seed orchard by RAPD analysis with a bulking procedure. Silvae Genetica 50: 271-275.

Goto, S., F. MiYAHARA and Y. IDE (2002a): Monitoring male reproductive success in a Japanese black pine clonal seed orchard with RAPD markers. Can J For Res 32: 983-988.

Goto, S., F. MiYAhaRA and Y. IDE (2002b): Contribution of pollen parents to the nematode-resistance in seedlings of Japanese black pine. J Jpn For Soc 84: 45-49 (Japanese with English summary).

Grattapaglia, D., V. J. Ribeiro and G. D. S. P. Rezende (2004): Retrospective selection of elite parent tree using paternity testing with microsatellite markers: an alternative short term breeding tactics for Eucalyptus. Theor Appl Genet 109: 192-199.

HARJU, A. and O. MuONA (1989): Background pollination in Pinus sylvestris seed orchards. Scand J For Res 4: 513-520.
KAng, K. S., D. Lindaren and T. J. Mullin (2001): Prediction of genetic gain and gene diversity in seed orchard crops under alternative management strategies. Theor Appl Genet 103: 1099-1107.

KAWAUCHI, H. and S. GoTo (1999): Monitoring clonal management in nematode-resistant Japanese black pine seed orchard in Kagoshima prefecture. J Jpn For Soc 81: 338-340 (Japanese with English summary).

LiAn, C., M. Miwa and T. Hogetsu (2000): Isolation and characterization of microsatellite loci from the Japanese red pine. Mol Ecol 9: 1186-1188.

Lian, C., M. Miwa and T. Hogetsu (2001): Outcrossing and paternity analysis of Pinus densiflora (Japanese red pine) by microsatellite polymorphism. Heredity 87: 88-98.

Marshall, T. C., J. Slate, L. E. B. KruUk and J. M. PemBERTON (1998): Statistical confidence for likelihoodbased paternity inference in natural populations. Mol Ecol 7: 639-655.

Moriguchi, Y., H. TAIRA, N. TANI and Y. Tsumura (2004): Variation of parental contribution in a seed orchard of Cryptomeria japonica determined using microsatellite markers. Can J For Res 34: 1683-1690.

Pakkanen, A., T. Nikkanen and P. Pulkkinen (2000): Annual variation in pollen contamination and outcrossing in a Picea abies seed orchard. Scand J For Res 15: 399-404.

Plomion, C., G. LeProvost, D. Pot, G. Vendramin, S. Gerber, S. DecroocQ, J. Brach, A. Raffin and P. PAstuszka (2001): Pollen contamination in a maritime pine polycross seed orchard and certification of improved seeds using chloroplast microsatellites. Can J For Res 31: 1816-1825.

Schoen, D. J. and S. C. Stewart (1986): Variation in male reproductive investment and male reproductive success in white spruce. Evolution 40: 1109-1120.

SEIDO, K. (2001): Genetic and breeding studies on pollen management in Hinoki (Chamaecyparis obtusa) seed orchard. Bull Yamanashi For Res Inst 22: 13-64 (in Japanese with English summary).

SILEN, R. R. (1962): Pollen dispersal considerations for Douglas-fir. J For 60: 790-795.

Stoenr, M. U. and C. H. NEWTON (2002): Evaluation of mating dynamics in a lodgepole pine seed orchard using chloroplast DNA markers. Can J For Res 32: 469-476.

Stoehr, M. U., B. L. ORvar, T. M. Vo, J. R. GAWLEY, J. E. WebBer and C. H. NewTon (1998): Application of a chloroplast DNA marker in seed orchard management evaluations of Douglas-fir. Can J For Res 28: 187-195.

Stoehr, M. U., J. E. Webber, C. C. A. Hollefreund and R. A. PAInTER (2004): Potential pollen contamination effects on progeny from an off-site Douglas-fir seed orchard: 9-year field results. Can J For Res 34: 981-984.

Streiff, R., A. Ducousso, C. Lexer, H. Steinkellner, J. Gloessl and A. KREMER (1999): Pollen dispersal inferred from paternity analysis in a mixed oak stand of Quercus robur L. and Q. petraea (Matt.) Liebl. Mol Ecol 8: $831-841$.

TANG, D.-Q. and Y. IDE (1998): Detection of genetic variation among seed and seedlings of Chamaecyparis obtusa using allozyme markers. J For Res 3: 35-38.

Toda, T., K. Nshimura, M. TAJIMA (1994): Some characteristics of the resistant pine clones to the pine-wood nematode (IX) - Flowering period of male and female flowers of resistant pine clone -. Kyushu Br Jpn For Soc 47: 53-4 (In Japanese). 
TODA, T., M. TAJIMA, K. NishimURA and H. TAKEUCHI (1993): Resistance breeding to the pine wood nematode in Kyushu district - Progress of study after selection of the resistant clones. Bull For Tree Inst 11: 37-88 (in Japanese with English summary).

VAN DE VEN, W. T. G. and R. J. MCNicOL (1995): The use of RAPD markers for the identification of Sitka spruce (Picea sitchensis) clones. Heredity 75: 126-132.

Wang, C.-W., T. O. Perry and A. G. Johonson (1960): Pollen dispersion of slash pine (Pinus elliotii Engelm.) with special reference to seed orchard management. Silvae Genetica 9: $78-86$.

WheELER, N. C. and K. S. JECH (1992): The use of electrophoretic markers in seed orchard research. New Forests 6: 311-328.

Williams, J. G. K., A. R. KubELIK, K. J. LivAK, J. A. RAFALSKI and S. V. TINGEY (1990): DNA polymorphisms amplified by arbitrary primers are useful as genetic markers. Nucleic Acids Res 18: 6531-6535.

\title{
Seed Source Variation in Morphology, Germination and Seedling Growth of Jatropha curcas Linn. in Central India
}

\author{
By H. S. Ginwal ${ }^{1, *}$, S. S. Phartyal ${ }^{1}$, P. S. RawaT ${ }^{2}$ and R. L. SRIVAstava ${ }^{3}$
}

(Received 10 ${ }^{\text {th }}$ May 2005)

\begin{abstract}
The aim of the study was to determine source variation in Jatropha curcas seeds collected from ten locations in Central India. A significant seed source variation was observed in seed morphology (colour, size and weight), seed germination (viability, germination percent, germination energy, germination value) and seedling growth parameters (survival percentage, seedling height, collar diameter, leave/plant, and seedling biomass). The seed source of Chhindwara (M.P.) was found as the best source in comparison to others. The phenotypic and genotypic variance, their coefficient of variability and broad sense heritability also showed a sizeable variability. This offers a breeder ample scope to undertake screening and selection of seed sources for the desired traits. Further, high percentage of heritability coupled with moderate intensity of genetic gain, was observed for seed germination traits, which signifies that germination is under strong genetic control and good amount of heritable additive genetic component can be exploited for improvement of this species.
\end{abstract}

Key words: Jatropha curcas, variation, seed source, variability, heritability, genetic gain, seed germination, germination energy.

\section{Introduction}

Jatropha curcas Linn. (physic nut or Ratanjot), a genus of family Euphorbiaceae, is believed to be a native of Mexico and Central America. It has been introduced in Africa and Asia and is now cultivated worldwide. Por-

\footnotetext{
1) Division of Genetics and Tree Propagation, Forest Research Institute, PO- I.P.E., Kaulagarh Road, Dehradun-248195, UA, INDIA.

$\left.{ }^{2}\right)$ Research and Coordination Section, Forest Research Institute, PO- New Forest, Dehradun-248006, UA, INDIA.

3) Arid Forest Research Institute, PO-Krishi Mandi, New Pali Road, Jodhpur-342005, Rajashthan, INDIA

*) Authors for corresponding: ginwalhs@rediffmail.com
}

tuguese introduced physic nut as an oil yielding plant in India. It is a multipurpose, deciduous, small tree (or large shrub), reported to be cultivated in drier sites of central and western parts of India. Recently, it has also been introduced in the northern and southern states under massive plantation work to enhance livelihood of rural people and simultaneously to develop wasteland. Jatropha curcas is a prominent species with vide variety of uses. Seeds, leaves and bark are used in traditional medicine and for veterinary purposes. The oil has a strong purgative action and is also widely used for skin diseases and to soothe rheumatic pain. A decoction of leaves is used against cough and as an antiseptic after birth (HELLER, 1996).

In recent years energy conservation and its alternative production has acquired significant importance in the wake of the world energy crisis. Since the oil crisis of the 1970s and recognition of the limitations of world oil resources, most of the oil importing countries including India has been highly motivated to develop alternative sources of energy to meet their domestic needs from natural resources. J. curcas has been found highly promising species which can yield oilseed as a source of energy in the form of bio-diesel owing to its short gestation period, hardy nature, high quality oil content, etc. The oil can also be used in soap and candle industries and its by-product glycerine can be used in the pharmaceutical industry.

Considering vast semi-wild distribution of J. curcas in different parts of India, it would be expected to have considerable genetic variation. Sufficient information on such aspect is lacking in this species in spite of its many uses. Environmental factors in combination with genetic and physiological factors play important role in determination of plant potential for seed quality. These characters appear to be under strong genetic control (Roy et al., 2004). Depending on the species, germination 